\title{
Revision of moles in the genus Scapanus
}

\author{
Sergio Ticul Álvarez-Castañeda ${ }^{1 *}$, and Patricia Cortes-Calva ${ }^{1}$ \\ ${ }^{1}$ Centro de Investigaciones Biológicas del Noroeste, Instituto Politécnico Nacional 195, CP. 23096. La Paz, Baja California Sur, \\ México. Email: sticul@cibnor.mx (STA-C), pcortes04@cibnor.mx (PCC). \\ ${ }^{*}$ Corresponding author
}

\begin{abstract}
Scapanus latimanus is a species with many morphological differences among its populations. This variation is associated with multiple taxonomic changes at the species or subspecies level. This study incorporates genetic analyses and comparisons with previous morphological studies to propose a better understanding of the latimanus complex. Mitochondrial markers (cytochrome b; cytochrome $c$ oxidase subunit l; and cytochrome c oxidase subunit III) were sequenced to construct a phylogeny for the subfamily Scalopinae in North America. Genetic distances ranged from 2.49 to $10.50 \%$ among geographic areas. Results identified three monophyletic clades with high bootstrap support values. Based on our phylogenetic analysis and previous morphological analyses, we confirm S. anthonyi from San Pedro Mártir as a valid species and propose that S. occultus from southern California and northern Baja California peninsula be considered as a species.
\end{abstract}

Scapanus latimanus es una especie con muchas diferencias morfológicas entre sus poblaciones. Esta variación está asociada con múltiples cambios taxonómicos a nivel de especie o subespecie. Para proponer una mejor comprensión del complejo latimanus, en este estudio se incorpora la información genética a los estudios previos de morfología. Se secuenciaron genes de origen mitocondrial (citocromo b; citocromo c oxidasa subunidad I y III) para construir la filogenia para la subfamilia Scalopinae en Norteamérica. Se obtuvieron distancias genéticas con un intervalo entre 2.49 a $10.50 \%$ entre áreas geográficas. Los resultados identifican tres clados monofiléticos con altos valores de soporte. Con base en la comparación del análisis filogenético e información morfológica previa conocida, se confirma como una especie válida a S. anthonyi de San Pedro Mártir y proponemos que S. occultus del sur de California y norte de la península de Baja California también sea considerada como una especie.

Keywords: Molecular markers; moles; North America; phylogeny; Scalopinae; Talpidae; taxonomy.

(C) 2021 Asociación Mexicana de Mastozoología, www.mastozoologiamexicana.org

\section{Introduction}

The family Talpidae includes three subfamilies, Scalopinae, Talpinae, and Uropsilinae, with Scalopinae being restricted to America and containing four genera Condylura, Parascalops, Scalopus, and Scapanus (Shinohara et al. 2003; Hutterer 2005). Scapanus is the only genus including more than one species; S. latimanus, S. orarius, and S. townsendii (Hutterer 2005). A fourth species, S. anthonyi, has been considered, although it has undergone many taxonomic changes. $S$. anthonyi was described as a full species by Allen (1893), and later was considered to be a subspecies of S. latimanus (Palmer 1937). Palmer (1937) argued that morphometric characteristics of $S$. anthonyi, such as its smaller size and fewer number of upper premolars, also were present in S. I. occultus, and consequently, S. anthonyi should be considered a subspecies of S. latimanus (see: Palmer 1937; Hutchinson 1987).

In his review of American moles, Jackson (1915) recognized S. anthonyi as a species because S. anthonyi has a projection in the braincase between the interparietal and the mastoid, which was absent in S. I. occultus (Jackson 1915). However, Palmer (1937) did not acknowledge these characteristics in the specimens that he examined, and therefore did not consider S. anthonyi a valid species. Huey (1936) suggested an additional difference between S. I. occultus and S. anthonyi; specifically, the manus (part of the pentadactyl limb that includes the metacarpals and phalanges) in S. anthonyi is squarer and smaller, with broader and heavier phalanges and with tips of the pterygoids parallel. In an alternative view, Hutchinson (1987) suggested that S. anthonyi shared characteristics with S. orarius; however, he continued to recognize $S$. anthonyi as a subspecies of $S$. latimanus. Populations of S. anthonyi in San Pedro Mártir, Baja California and those of S. I. grinnelli and S. I. occultus in southern California and northern Baja California peninsula are smaller in size and the skull is wider in relation to all other subspecies of S. latimanus from central and northern California (Yates and Salazar-Bravo 2005). Differences in skull morphology also occur between these two groups. $S$. anthonyi has only two or three upper premolars, and the temporal fossae is larger (Allen 1893; Jackson 1915; Huey 1936; Yates and Salazar-Bravo 2005).

Previous morphological analyses of all subspecies of S. latimanus indicated that some subspecies should be junior synonyms (Yates and Salazar-Bravo 2005) of other subspecies. For example, S. I. grinnelli (Jackson 1914) of S. I. occultus (Grinnell and Storer 1916); S. dilatus (True 1894), S. alpinus (Merriam 1897), and S. I. caurinus (Palmer 1937) of S. I. latimanus (Bachman 1842); S. I. sericatus (Jackson 1914), S. I. campi (Grinnell and Storer 1916), and S. I. monoensis (Grinnell 1918) of S. I. minusculus (Bangs 1899). However, S. I. insularis (Palmer 1937) and S. I. parvus (Palmer 1937) were not subjected to taxonomic changes (Yates and Salazar-Bravo 2005). 
Based on these previous studies, the taxonomic status of species within the $S$. latimanus group has revealed several inconsistencies. The goal of this study is to better define the phylogenetic relationships of populations within Scapanus and combine these relationships with known morphological characteristics to evaluate the potential number of species. To achieve this goal, three mitochondrial genes were sequenced: cytochrome $b(C y t b ; n=23)$; cytochrome $c$ oxidase subunit I (Col, $n=29)$; and cytochrome $c$ oxidase subunit III (CO3; $n=29)$.

\section{Materials and Methods}

Sample collection. The dataset included specimens of the genus Scapanus $(n=31)$ represented by the species $S$. orarius, S. townsendi, S. latimanus, and outgroup specimens of Condylura, Neurotrichus, and Scalopus $(n=6)$. Tissue samples were obtained from the Collection of Mammalian tissues at Centro de Investigaciones Biológicas del Noroeste (CIB), Field Museum of Natural History (FMNH), Museum of Southwestern Biology at the University of New Mexico (MBS), and Museum of Vertebrate Zoology at the University of California (MVZ). Information for localities and museum catalog numbers are provided in Table 1. All capture and handling methods followed the animal care and use guidelines of the American Society of Mammalogists (Sikes et al. 2016). For all analyses, we grouped specimens from these localities into three species, S. orarius, S. townsendi, and S. latimanus, with S. latimanus further subdivided into three geographic units: 1) central and northern California (Group A, localities 7-14); 2) southern California and northern Baja California peninsula (Group B, localities 15-17); and 3) Sierra de San Pedro Mártir (Group C, locality 18; Figure 1; Table 1). This resulted in 31 geographic samples of Scalopinae.

DNA extraction and PCR conditions. Genomic DNA was extracted from muscle tissue preserved in $95 \%$ ethanol (archived at $-20^{\circ} \mathrm{C}$ ) or frozen (archived at $-80^{\circ} \mathrm{C}$ ) using the DNAeasy Kit (QIAGEN Inc., Valencia, CA) protocols.

The following conditions were used for the initial double-strand amplification: $12.5 \mu \mathrm{l}$ of (10 $\mathrm{ng}$ ) template, $4.4 \mu \mathrm{l}$ $\mathrm{ddH} 2 \mathrm{O}, 2.5 \mu \mathrm{l}$ of each primer pair (10 $\mathrm{nM}$ concentration), $0.474 \mu \mathrm{l}(0.4 \mathrm{nM}) \mathrm{dNTPs}, 0.5 \mu \mathrm{l}(3 \mathrm{mM}) \mathrm{MgCl}_{2}, 0.125 \mu \mathrm{l}$ Taq polymerase (platinum, Invitrogen, Carlsbad, CA), and $1 \times$ Taq buffer, to a final volume of $25 \mu \mathrm{l}$. The amplification conditions consisted of an initial denaturation at $94{ }^{\circ} \mathrm{C}$ for $3 \mathrm{~min}$ followed by 37 denaturation cycles at $94{ }^{\circ} \mathrm{C}$ for $45 \mathrm{~s}$ each; $60 \mathrm{~s}$ annealing at $50{ }^{\circ} \mathrm{C}(\mathrm{Cytb}), 51^{\circ} \mathrm{C}(\mathrm{Co} 1), 55^{\circ} \mathrm{C}$ (Co3); and extension at $72{ }^{\circ} \mathrm{C}$ for $60 \mathrm{~s}$; the products of the PCR amplification were verified in agarose gel, purified and sequenced both ways using the sequencing service of Macrogen Inc, Korea. The first part of the cytochrome b (Cytb, $\sim 800 \mathrm{bp}$ ) gene was amplified using the primers MVZ05/ MVZ16 (primer sequences given in Smith and Patton 1993; Smith 1998), the 658-bp fragment of cytochrome c oxidase subunit I (Co1) was amplified with the primers LCO1490/ HCO2198 (Ivanova et al. 2007), and the 717-bp fragment of cytochrome c oxidase subunit III (Co3) was amplified with the primers L8618/H9323 (Riddle 1995). We aligned nucleotide sequences in Sequencher ver. 3.1 (Gene Codes Corp., Ann Arbor, Michigan), verified alignments visually, and translated them into amino acids for alignment confirmation. The haplotypes generated and used were deposited in GenBank (Table 1).

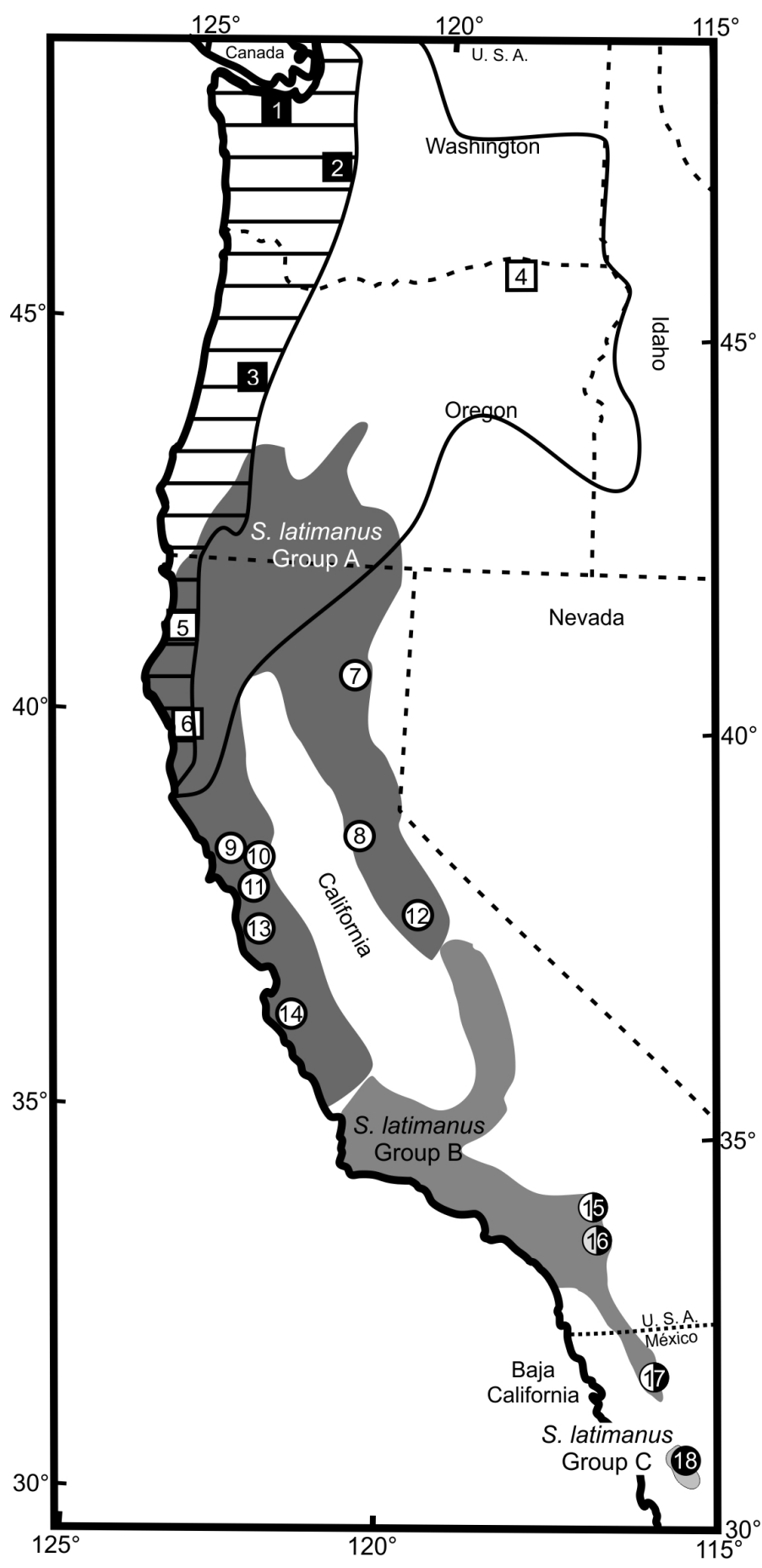

Figure 1. Distribution map of the species of the subfamily Scalopinae in North America. Scapanus townsendi (solid squares 1-3), S. orarius (open squares 4-6), and S. latimanus (circles). S. latimanus is split into three geographic groups: A) Central and northern California (localities 7-14, light gray circle); B) Southern California and northern Baja California peninsula (localities 15-17, half light/half dark circles); and C) Sierra de San Pedro Mártir (locality 18, dark gray circle). 


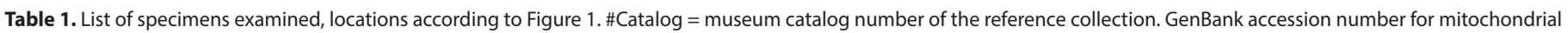
marker. Group (Gr), Number of map (M), State (ST), * Zhao and Jian 2015. ${ }^{*}$ Mouchaty et al. 2000.

\begin{tabular}{|c|c|c|c|c|c|c|c|c|c|c|}
\hline Gr & $\mathbf{M}$ & Species & \#Catalog & St & Locality & Lat & Long & Co1 & $\mathrm{CO3}$ & Cytb \\
\hline & & & & & & & & \multicolumn{3}{|c|}{ GenBank accession numbers } \\
\hline & 1 & Scapanus t. olympicus & MSB 43550 & WA & 9.2 Mi S, 2.7 Mi W Port Angeles & 47.9851 & -123.4878 & MZ150455 & MZ217155 & MZ217129 \\
\hline & 1 & Scapanus t. olympicus & MSB 43552 & WA & 9.2 Mi S, 2.7 Mi W Port Angeles & 47.9851 & -123.4878 & MZ150456 & MZ217156 & MZ217130 \\
\hline & 2 & Scapanus t. towsendii & MVZ 220251 & WA & $24303 \mathrm{Se}$ 468th Street, Enumclaw & 47.1809 & -122.0175 & MZ150457 & MZ217157 & \\
\hline & 2 & Scapanus t. towsendii & MVZ 220252 & WA & $24303 \mathrm{Se}$ 468th Street, Enumclaw & 47.1809 & -122.0175 & MZ150458 & MZ217158 & \\
\hline & 4 & Scapanus t. townsendii & MSB 40780 & OR & 9 Mi E Alsea & 44.3817 & -123.4135 & MZ150459 & MZ217159 & MZ217131 \\
\hline & 4 & Scapanus t. townsendii & MSB 40781 & OR & 9 Mi E Alsea & 44.3817 & -123.4135 & MZ150460 & MZ217160 & MZ217132 \\
\hline & 3 & Scapanus o. schefferi & MSB 54620 & WA & 2 Mi W Walla Walla & 46.0647 & -118.3835 & MZ150461 & MZ217161 & MZ217133 \\
\hline & 3 & Scapanus o. schefferi & MSB 54621 & WA & Country Club, Walla Walla & 46.0389 & -118.3503 & MZ150462 & MZ217162 & MZ217134 \\
\hline & 5 & Scapanus o. orarius & MSB 43626 & CA & 3.8 Mi S, 2.7 Mi E Trinidad & 41.004 & -124.0916 & & MZ217163 & MZ217135 \\
\hline & 5 & Scapanus o. orarius & MSB 43627 & CA & 3.8 Mi S, 2.7 Mi E Trinidad;T7n, R1e, Sec 8 & 41.004 & -124.0916 & MZ150463 & MZ217164 & MZ217136 \\
\hline & 5 & Scapanus o. orarius & MSB 43628 & CA & 3.8 Mi S, 2.7 Mi E Trinidad;T7n, R1e, Sec 8 & 41.004 & -124.0916 & MZ150464 & & \\
\hline & 7 & Scapanus o. orarius & MVZ 224399 & CA & 11 Mi N Westport On Hwy 1. & 39.7506 & -123.819 & MZ150465 & MZ217165 & \\
\hline \multirow[t]{9}{*}{ A } & 6 & Scapanus I. dilatus & MVZ 217713 & CA & Eagle Lake Road (Lassen Co. A1), Eagle Lake. & 40.6235 & -120.8399 & MZ150466 & MZ217166 & MZ217137 \\
\hline & 8 & Scapanus I. dilatus & MSB 47919 & CA & $1 \mathrm{Mi}$ S, 4.5 Mi E Somerset, 2850 & 38.6334 & -120.5984 & MZ150467 & MZ217167 & MZ217138 \\
\hline & 9 & Scapanus I. caurinus & MVZ 216930 & CA & Easy Sweet Farm, Sebastapol & 38.472 & -122.8544 & MZ150468 & MZ217168 & \\
\hline & 10 & Scapanus I. caurinus & MVZ 199506 & CA & 2930 Redwood Road, Napa & 38.3167 & -122.3385 & MZ150469 & MZ217169 & MZ217139 \\
\hline & 11 & Scapanus I. latimanus & MVZ 218027 & CA & 103 Aldarado Rd., Berkeley & 37.8579 & -122.2396 & MZ150470 & & \\
\hline & 12 & Scapanus I. latimanus & MVZ 201320 & CA & Forest S of Chapel, Yosemite Valley & 37.7408 & -119.5907 & & MZ217170 & \\
\hline & 13 & Scapanus I. latimanus & MSB 48532 & CA & Palo Alto, Stanford University Campus & 37.429 & -122.1695 & MZ150471 & MZ217171 & MZ217140 \\
\hline & 14 & Scapanus I. latimanus & MVZ 222251 & CA & Hastings Natural History Reservation & 36.3785 & -121.5568 & MZ150472 & MZ217172 & \\
\hline & 14 & Scapanus I. latimanus & MVZ 228295 & CA & Haystack Hill, Hastings Natural History Reservation & 36.3847 & -121.5627 & MZ150473 & MZ217173 & MZ217141 \\
\hline \multirow[t]{7}{*}{ B } & 15 & Scapanus I. occultus & MSB 47311 & CA & 10 Mi Se Big Bear City, Heart Bar campground & 34.1586 & -116.786 & MZ150474 & MZ217174 & MZ217142 \\
\hline & 16 & Scapanus I. occultus & MSB 47317 & CA & 3.6 Mi N, 9.8 Mi E Hemet, Lake Fulmor & 33.8052 & -116.7785 & MZ150475 & MZ217175 & MZ217143 \\
\hline & 17 & Scapanus I. occultus & MSB 43120 & $\mathrm{BC}$ & Laguna Hanson & 32.0489 & -115.9056 & MZ150476 & MZ217176 & MZ217144 \\
\hline & 17 & Scapanus I. occultus & MSB 40343 & $\mathrm{BC}$ & Laguna Hanson & 32.0489 & -115.9056 & MZ150477 & MZ217177 & MZ217145 \\
\hline & 17 & Scapanus I. occultus & MSB 40344 & $\mathrm{BC}$ & Laguna Hanson & 32.0489 & -115.9056 & MZ150478 & MZ217178 & MZ217146 \\
\hline & 17 & Scapanus I. occultus & MSB 40345 & $\mathrm{BC}$ & Laguna Hanson & 32.0489 & -115.9056 & MZ150479 & MZ217179 & MZ217147 \\
\hline & 17 & Scapanus I. occultus & MSB 47308 & $\mathrm{BC}$ & Sierra Juárez, Laguna Hanson & 32.0489 & -115.9056 & MZ150480 & MZ217180 & MZ217148 \\
\hline \multirow[t]{3}{*}{ C } & 18 & Scapanus I. anthonyi & MSB 47306 & $\mathrm{BC}$ & Sierra San Pedro Mártir, 3.9 Mi by Road W Vallecitos & 31.0167 & -115.5333 & MZ150481 & MZ217181 & MZ217149 \\
\hline & 18 & Scapanus I. anthonyi & CIB 32000 & $\mathrm{BC}$ & Sierra San Pedro Mártir & 31.0167 & -115.5333 & MZ150482 & MZ217182 & MZ217150 \\
\hline & 18 & Scapanus I. anthonyi & MSB 47307 & $\mathrm{BC}$ & Sierra San Pedro Mártir, 20 Mi S, 10.9 Mi E Vallecitos & 31.0167 & -115.5333 & MZ150483 & MZ217183 & MZ217151 \\
\hline \multirow{6}{*}{$\begin{array}{l}\text { Out- } \\
\text { group }\end{array}$} & & Condylura cristata & KU144678* & & & & & KU144678 & & \\
\hline & & Condylura cristata & NC029762* & & & & & NC_029762 & & \\
\hline & & Neurotrichus g. hyacinthinus & MVZ 200061 & $\mathrm{CA}$ & Headwaters of Big Austin Creek, N of Cazadero & 38.6138 & -123.1315 & MZ150484 & MZ217184 & MZ217152 \\
\hline & & Scalopus a. machrinus & FMNH 167212 & $\mathrm{Ml}$ & Fennville & 42.5939 & -86.1017 & MZ150485 & MZ217185 & MZ217153 \\
\hline & & Scalopus a. machrinus & FMNH 167213 & MI & Fennville & 42.5939 & -86.1017 & MZ150486 & MZ217186 & MZ217154 \\
\hline & & Talpa europaea & Y19192 ** & & & & & Y19192 & & \\
\hline
\end{tabular}

Phylogenetics analysis. The methodology for phylogenetic analysis was similar to that used by Camargo and Álvarez-Castañeda (2020). The most appropriate substitution model for the dataset for each of the three gene regions, as well as for the concatenated series, was determined using the Akaike information criterion (AIC) as implemented in MrAIC (Nylander 2004). Four separate Bayesian inference and maximum-likelihood analyses were conducted on the three genes independently; the concatenated series had three partitions with one per gene (Cytb, Co1, and Co3). 
Bayesian analyses were implemented in (MrBayes ver. 3.0b4; Huelsenbeck and Ronquist 2001) with four separate runs with Markov-chain Monte Carlo simulations starting from a random tree. Each run was conducted for 20 million generations and sampled at intervals of 1,000 generations. Of the samples trees, the first $50 \%$ were discarded as burnin and all remaining trees were analyzed to find the posterior probability of resulting nodes. A consensus tree was generated with the $50 \%$ majority-rule algorithm in PAUP 4.0b10 (Swofford 2002). The percentage of samples recovered in a particular clade was assumed to be the posterior probability of that clade in PAUP 4.0b10 using a heuristic search with 1,000 replicates and swapping with the TBR algorithm.

Maximum-likelihood (ML) analyses were performed in PAUP ver. $4.0 b 10$ (Swofford 2002) algorithm (Felsenstein 1981) using a heuristic search with 1,000 replicates and swapping with the TBR algorithm. Reliability was assessed using each of the three codon positions individually while applying equal weights and nodal support using nonparametric bootstrapping. Members of each genus were used because although some phylogenetic analyses were done using allozymes (Yates and Greenbaum 1982; Moore 1986) the phylogenetic relationships among moles of North America were not previously examined using gene sequencing. Trees were rooted with Scalopini (Scalopus aquaticus), Urotrichini (Neurotrichus gibbsii), and Condylurini (Condylura cristata; Motokawa 2004).

\section{Results}

Phylogenetic analyses. AIC tests revealed that the best evolution model was a GTR model: Cytb (GTR + I + G), Co1 (GTR $+\mathrm{I}), \operatorname{Co3}(\mathrm{GTR}+\mathrm{G})$, and the concatenated genes $(\mathrm{GTR}+\mathrm{I}+$ $\mathrm{G}$ ). Bl and ML trees for Cytb, Co1, and Co3, and the concatenated data with four partitions converged on an essentially identical topology (Figure 2).

Analyses of the three genes within Scapanus resolved five haplogroups with strong bootstrap support (>95\%), as follows. Haplogroup 1: only specimens from San Pedro Mártir, Group C of S. latimanus; Haplogroup 2: specimens from southern California and northern Baja California peninsula, Group B of S. latimanus; Haplogroup 3: all S. latimanus specimens from Group A of central and northern California; Haplogroup 4: specimens of the two subspecies of $S$. townsendi with a very low percentage of differences between them; and Haplogroup 5: containing two groups, each with specimens of different subspecies of $S$. orarius (Figure 2).

Scapanus latimanus Group C (Haplogroup 1) is separated from the other S. latimanus Groups A and B by two different species, S. townsendi (Haplogroup 4) and $S$. orarius (Haplogroup 5). The percentage of pairwise genetic differences ( $p$-distance) for the three genes between Group C (San Pedro Mártir) and each of Group A (northern California) and Group B (southern California and northern Baja California) ranged from 7.22 to $10.50 \%$. The genetic differences between Group A and Group B ranged from 2.49 to $5.75 \%$ (Table 2 ).

\section{Discussion}

Genetic data revealed that S. townsendi and S. orarius are monophyletic and sibling taxa, as reported by Shinohara et al. (2003), and are substantially different from S. latimanus, as previously reported by Moore (1986). However, the geographic groups of S. latimanus do not exhibit a north-south phylogenetic relationship. The S. latimanus Group C from San Pedro Mártir formed an inconsistent relationship with the other two S. latimanus haplogroups from California and the northern Baja California peninsula (Haplogroups 2 and 3). Genes Co3 (boot $=56$ ) and Cytb (boot $=68$ ) show S. latimanus Group C (San Pedro Mártir) as a sister group to specimens from southern California and Baja California. However, analyses of $\mathrm{Co} 1$ (boot $=95$ ) and the concatenated group (boot $=95$ ) show S. latimanus Group $C$ basal to all Scapanus clades (boot $=95$ ), including $S$. townsendi and $S$. orarius (Figure 2). Each of the topologies show that S. latimanus Group C differs from Groups A and B. Although Hutchinson (1987) reported that S. anthonyi shared characteristics with $S$. orarius, this was not supported by the sequence data.

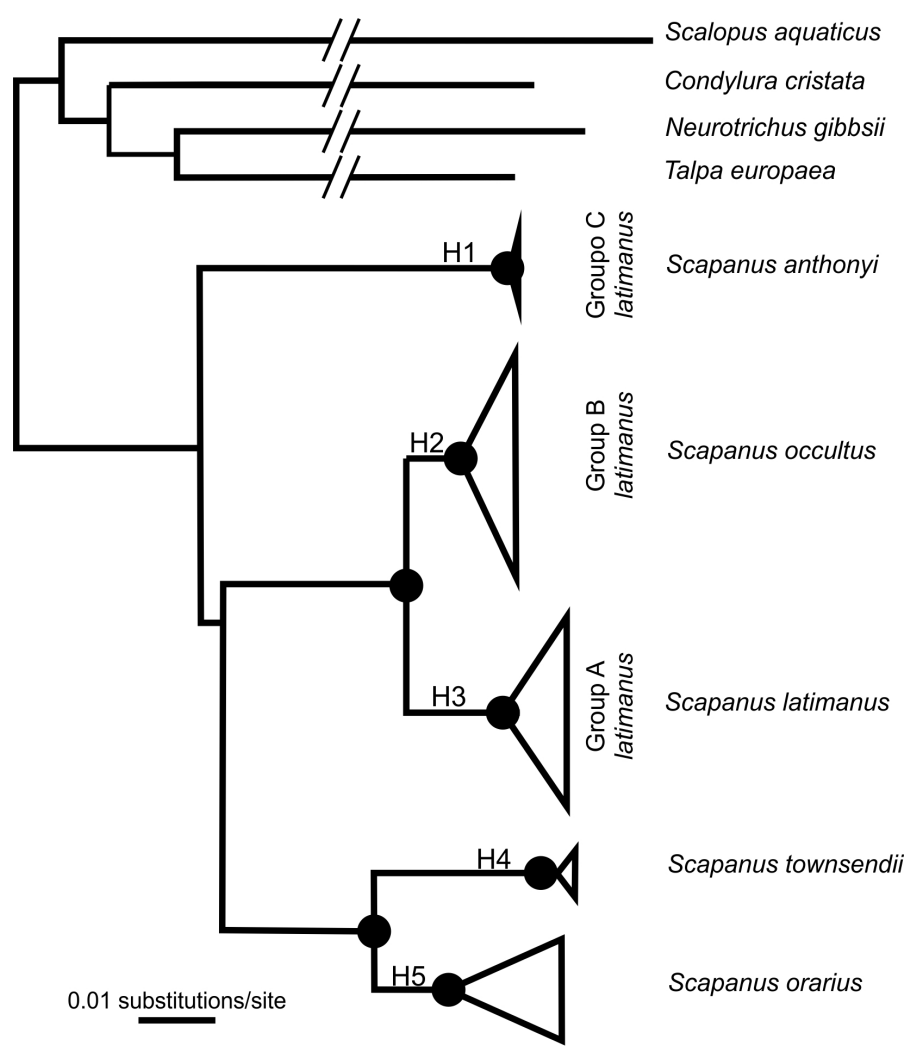

Figure 2. Bayesian tree constructed from three mitochondrial DNA genes (cytochrome $b$, cytochrome oxidase subunit I, and cytochrome oxidase subunit III) from members of the subfamily Scalopinae in North America and one of Talpa from Europe. Haplogroup 1 contains a single specimen from San Pedro Mártir, Group C of S. latimanus (S. anthonyi). Haplogroup 2 contains specimens from southern California and northern the Baja California peninsula, Group B of S. latimanus (S. occultus). Haplogroup 3 contains specimens from central and northern California, Group A of S. latimanus (S. latimanus). Haplogroup 4 is represented by two subspecies of $S$. townsendi. Haplogroup 5 is represented by two subspecies of $S$. orarius. 
We did not perform a morphometric analysis of the craniodental measurements because this previously was reported by Yates and Salazar-Bravo (2005). Yates and Salazar-Bravo (2005) reported statistical differentiation in morphological characters between S. I. occultus and S. anthonyi separated by a distance $>50 \mathrm{~km}$. In addition, they found significant differences between S. I. occultus and S. I. latimanus sensus (Yates and Salazar-Bravo 2005), with S. I. occultus being smaller overall. No specimens of S. I. occultus and S. I. latimanus have been collected in sympatry and in the two areas where S. I. occultus and S. I. latimanus occur, namely the southern part of Sierra Nevada and northern portion of Santa Barbara, it appears that S. I. occultus occurs in lower altitudes, and S. I. latimanus at higher altitudes.

Based on the genetic distance values between Groups A, B, and C, coupled with the morphological differences between them (Yates and Salazar-Bravo 2005), these

Table 2. Genetic distances (pairwise distance, $p$ ) among samples of the three geographical groups of Scapanus latimanus, S. orarius, and S. townsendi for the mitochondrial cytochrome $b(C y t b)$, cytochrome oxidase subunit I (Co1), and cytochrome oxidase subunit III (Co3).

\begin{tabular}{|c|c|c|c|}
\hline & Group A & Group B & Group C \\
\hline \multicolumn{4}{|c|}{ S. latimanus Group A (central and northern California) } \\
\hline Cytb & $0.13-1.96$ & $4.13-5.75$ & $8.00-9.67$ \\
\hline Co1 & $0.00-1.22$ & 2.59-3.65 & $9.59-10.50$ \\
\hline $\mathrm{Co3}$ & $0.15-0.61$ & $2.49-3.60$ & $7.89-8.58$ \\
\hline Concatenated & $0.24-1.23$ & $3.27-4.17$ & $8.53-8.95$ \\
\hline \multicolumn{4}{|c|}{ S. latimanus Group B (southern California and northern Baja California) } \\
\hline Cytb & $4.13-5.75$ & $0.0-1.50$ & $7.88-9.52$ \\
\hline Co1 & $2.59-3.65$ & $0.00-0.90$ & $8.68-9.98$ \\
\hline $\mathrm{Co3}$ & $2.49-3.60$ & $0.0-0.92$ & $7.22-7.55$ \\
\hline Concatenated & $3.27-4.17$ & $0.00-0.99$ & $7.82-8.01$ \\
\hline \multicolumn{4}{|c|}{ S. latimanus Group C (San Pedro Mártir) } \\
\hline Cytb & $8.00-9.67$ & $7.88-9.52$ & $0.00-1.75$ \\
\hline Co1 & $9.59-10.50$ & $8.68-8.98$ & $0.00-0.15$ \\
\hline $\operatorname{Co3}$ & $7.89-8.58$ & $7.22-7.55$ & $0.00-0.15$ \\
\hline Concatenated & $8.53-8.95$ & $7.82-8.01$ & $0.05-0.09$ \\
\hline \multicolumn{4}{|l|}{ S. orarius } \\
\hline Cytb & $6.75-8.66$ & $7.50-9.50$ & $8.00-9.89$ \\
\hline Co1 & 8.98-10.05 & $9.52-9.89$ & $9.44-10.20$ \\
\hline $\mathrm{Co3}$ & $8.06-10.14$ & $6.88-9.09$ & $8.40-9.61$ \\
\hline Concatenated & $8.05-9.00$ & $7.82-8.43$ & $8.72-9.00$ \\
\hline \multicolumn{4}{|l|}{ S. townsendi } \\
\hline Cytb & $8.00-9.39$ & $8.00-9.50$ & $9.75-11.14$ \\
\hline Co1 & $8.98-8.98$ & 7.91-8.98 & $9.59-10.20$ \\
\hline $\mathrm{Co3}$ & $8.92-9.79$ & 7.72-8.75 & $9.09-9.61$ \\
\hline Concatenated & $8.67-9.19$ & $8.40-8.72$ & $9.43-9.62$ \\
\hline
\end{tabular}

groups can be considered as different species. The main morphological variations in the specimens of these groups are a smaller size in relation to the northern populations of S. latimanus and the variation in the number of upper premolars (Palmer 1937; Yates and Salazar-Bravo 2005).

Further, based on the sequence data, Scapanus latimanus from northern and southern California form two haplogroups. Haplogroup 3 includes all the specimens assigned to S. latimanus Group A (northern California) and Haplogroup 2 includes Group B (southern California and north Baja California peninsula). The population from San Pedro Mártir previously was considered as a distinct species, S. anthonyi (Allen 1893; Jackson 1915; Huey 1936; Yates and Salazar-Bravo 2005) and later subsumed into S. latimanus based on morphological characters (although a large series of specimens was never reviewed, which may have biased the interpretation), based primarily on the smaller size and number of upper premolars (Palmer 1937; Hutterer 2005). The morphological analyses (Yates and Salazar-Bravo 2005) and genetic analyses performed in this study support the consideration of S. anthonyi as a distinct species and indicates that S. anthonyi is restricted in distribution to the San Pedro Mártir mountain range.

Based on our phylogenetic analysis and its morphological characteristics (Allen 1893; Jackson 1915; Huey 1936; Yates and Salazar-Bravo 2005), we support that S. anthonyi is a different species from S. latimanus. Additionally, we propose that specimens known as S. latimanus occultus (including S. I. grinnelli) from southern California and northern Baja California peninsula should be considered as a distinct species (S. occultus) different from S. latimanus from central and north California and from S. anthonyi inhabiting San Pedro Mártir. Therefore, we consider that the genus Scapanus contains five species that should be recognized as S. anthonyi, S. latimanus, S. occultus, S. orarius, and S. townsendi.

\section{Scapanus anthonyi Allen 1893}

1893. Scapanus anthonyi Allen, Bull Amer. Mus. Nat. Hist., 5:200, August. Type locality: "Sierra San Pedro Martir, $7000 \mathrm{ft}$, Baja California [México]". Adult male, skin and skull, American Museum of Natural History number 6313, collected by A. W. Anthony.

1937. Scapanus latimanus anthonyi Palmer, J. Mamm. 18:312, August. Name combination.

Geographic range. Restricted to the highlands of Sierra San Pedro Mártir, Baja California, México.

Diagnosis and comparison. Scapanus anthonyi can be differentiated from the other species of Scapanus in having fewer than seven unicuspid teeth behind the incisors in the mandible and maxilla and total skull length $<32.5$ $\mathrm{mm}$. Projection present in the braincase between the interparietal and the mastoid (Jackson 1915). Manus more square and smaller, with broader and heavier phalanges, tips of the pterygoids bones of the upper palate paral- 
lel (Huey 1936). Smaller in all craniodental and somatic measurements relative to all other subspecies of $S$. latimanus, and teeth larger and crowded (Yates and SalazarBravo 2005:494 in table 3). Differing from S. orarius and S. townsendii in a smaller in size; dorsal coloration darker, almost black; no spaces between all unicuspid teeth, usually crowded; and rostrum short and broad.

Comments. Scapanus anthonyi has a distribution restricted to the upper portions of the Sierra San Pedro Mártir, within the pine and oak-pine forest. Collecting moles in the region is complex for several reasons. First, the gopher Thomomys nigricans is very abundant in the same area, so it is common to find gophers galleries that impinge upon and destroy mole galleries. Second, both species share a sympatric distribution throughout the mountain range. Third, although this region is a protected area, large numbers of cattle graze in the area and destroy the mole galleries. Fourth, specimens of $S$. anthonyi are very small in size, so their galleries also are small and the soil relief (molehill) that results from gallery construction is very difficult to determine. Fifth, galleries have a simple structure, and raise just $3 \mathrm{~cm}$ above the ground, and any leaf litter makes these molehills invisible (Cortés-Calva pers. obs.).

In the area, both Scapanus and Thomomys are named "topos" (moles) with no distinction between them, and only old ranchers give different names to them. Scapanus are called "topos de manoplas" (baseball-gloved moles) in reference to its forefoot size. Thomomys are known only as "topos".

\section{Scapanus occultus Grinnell and Swarth 1912}

1912. Scapanus latimanus occultus Grinnel and Swarth, Univ. California, Publ. Zool., 10:131, April. Type locality: "Santa Ana canyon, $400 \mathrm{ft}$ (12 mi NE Santa Ana), Orange County California". Subadult female, skin and skull, Museum of Vertebrate Zoology, University of California, Berkeley, number 2369, collected by H. S. Swarth.

1914. Scapanus latimanus grinnelli Jackson, Proc. Biol. Soc. Washington, 27:56. Considered as junior synonym.

Geographic range. From Laguna Hanson (Sierra de Juárez) Baja California, México northwestward to Santa Barbara and northward to Yosemite Valley in Mariposa County, California.

Diagnosis and comparison. Scapanus occultus can be differentiated from S. latimanus in its smaller size and longer and wider skull (Yates and Salazar-Bravo 2005:494 in table 3). Some specimens have fewer than seven unicuspid teeth, but only on a single side of the mandible or maxilla. It differs from S. orarius and S. townsendii by the same characteristics mentioned in S. anthonyi.

\section{Scapanus latimanus (Bachman 1842)}

1842. Scapanus latimanus Bachman, Boston Jour. Nat. Hist., 4:34. Type locality "probably from Santa Clara, Santa Clara, California" Mounted specimen with imperfect skull, Berlin Museum, collected during October 1834.
1912. Scapanus latimanus latimanus Grinnell and Swarth, Univ. California, Publ. Zool., 10:131, April. First use of current name combination.

Geographic range. From Santa Barbara and Yosemite Valley, California, northward to southcentral Oregon.

Diagnosis and comparison. Scapanus latimanus can be differentiated from S. orarius and S. townsendii by the same characteristics mentioned in S. anthonyi.

\section{Keys for the species of Scapanus}

1. Dorsal coloration usually brown to gray. All unicuspid teeth with variable spacing between them and usually crowded; rostrum short and broad 2

1a. Dorsal coloration almost black. All unicuspid teeth with regular spacing between them, and not crowded; rostrum long and narrow

\section{4}

2. Fewer than seven unicuspid teeth behind the incisors in the mandible and maxilla; total skull length less than $32.5 \mathrm{~mm}$. Scapanus anthonyi

2a. Seven unicuspid teeth behind the incisors in the mandible and maxilla; total skull length $>32.5 \mathrm{~mm}$.............. 3

3. Total length $>161.0 \mathrm{~mm}$. Skull length $>34.0 \mathrm{~mm}$ in males and $33.4 \mathrm{~mm}$ in females. Ratio of mastoidal breadth to greatest skull length $<49 \%$, including the population of Alameda Island, California .. Scapanus latimanus

3a. Total length $<161.0 \mathrm{~mm}$. Skull length $<34.0 \mathrm{~mm}$ in males and $33.4 \mathrm{~mm}$ in females. Ratio of mastoidal breadth to greatest skull length $>49 \%$, not including the population of Alameda Island, California Scapanus occultus

4. Total length $>200.0 \mathrm{~mm}$ on average. Sublacrimalmaxillary ridge well developed; skull $>40.0 \mathrm{~mm}$ Scapanus townsendii

4a. Total length $<200.0 \mathrm{~mm}$ on average. Sublacrimalmaxillary ridge little developed; skull $<40.0 \mathrm{~mm}$

Scapanus orarius

\section{Acknowledgments}

We dedicate this article to "Dave" Schmidly as a small tribute to his great academic and scientific career. As a recognition of how much he has done for the understanding of Mammalogy, especially in México and to the great support that he has always had from his colleagues in the profession. Although, the authors of this article did not have the opportunity to work directly with him, we have been under what he helped create. In fact, Therya is a secondary product of what the impulse to create a few decades ago and today it is an important window for the dissemination of science that is done mainly in México and Latin America. We wish to express our appreciation to Joseph A. Cook, Jonathan L. Dunnum, and Mariel L. Campbell Museum of Southwestern Biology (MSB), The University of New Mexico. Bruce Patterson, Field Museum of Natural History (FMNH); James L. Patton and Christopher J. Conroy, Museum of Vertebrate 
Zoology at the University of California (MVZ); Vicky Mingna Zhuang, The University of Texas at El Paso (UTEP). We thank G. De León Girón (Parque Nacional Sierra San Pedro Mártir), for granting permission and logistic support, Fr. Arce and M. de La Paz Cuevas for their valuable assistance in the field; and G. Gallegos-Simental for her assistance in laboratory Node CIBNOR Barcode of Mexican Network of the Barcode of Life (MEXBOL), and C. I. Gutiérrez Rojas in laboratory work. This study received financial support (Grant 280896, 295569-CONACYT) Red temática CONACYT Código de Barras de la Vida, Maria Elena Sánchez-Salazar translated the manuscript into English.

\section{Literature Cited}

Allen, J. A. 1893. On a collection of mammals from San Pedro Martir region of Lower California. Bulletin American Museum Natural History 5:181-202.

Bangs, 0. 1899. Descriptions of some new mammals from western North America. Proceedings of the New England Zoological Club 1:65-72.

BaCHMAN, J. 1842. Observations on the genus Scalops, (shrew moles,) with descriptions of the species found in North America. Boston Journal of Natural History 4:26-35.

Camargo, I., and S. T. Álvarez-Castañeda. 2020. A new species and three subspecies of the desert shrew (Notiosorex) from the Baja California peninsula and California. Journal of Mammalogy 101:872-886.

FelSenstein, J. 1981. Evolutionary trees from DNA sequences: a maximum likelihood approach. Journal of Molecular Evolution 17:368-376.

GrinnelL, J. 1918. Six new mammals from the Mohave Desert and Inyo regions of California. University of California Publications in Zoology 17:423-430.

GrinNeLL, J., AND T. I. Storer. 1916. Diagnoses of seven new mammals from east-central California. University of California Publications in Zoology 17:1-8.

Grinnell, J., AND H. S. Swarth. 1912. The mole of southern California. University of California Publications in Zoology 10:131-136.

Huelsenbeck, J. P., And F. Ronquist. 2001. MRBAYES: Bayesian inference of phylogenetic trees. Bioinformatics 17:754-755.

Huey, L. M. 1936. Notes on the moles of Lower California, México. Journal of Mammalogy 17:166-167.

Hutchinson, J. H. 1987. Moles of the Scapanus latimanus Groups (Talpidae, Insectivora) from the Pliocene of California. Contributions in Science, Natural History Museum of Los Angeles County 386:1-15.

Hutterer, R. 2005. Order Soricomorpha Pp. 220-311, in Mammal species of the world. A taxonomic and geographic reference (Wilson, D. E., and D. A. M. Reeder, eds.). Third edition. The Johns Hopkins University Press. Baltimore, U.S.A.

Ivanova, N. V., S. T. Zemlak, R. H. Hanner, and P. Hebert. 2007. Universal primer cocktail for fish DNA barcoding. Molecular Ecology Notes 7:544-548

Jackson, H. H. T. 1914. New moles of the genus Scapanus. Proceedings of the Biological. Society of Washington 27:55-56.

JACKson, H. H. T. 1915. A review of the American moles. North American Fauna 38:1-100.
MerRiam, C. H. 1897 . The mammals of mount Mazama, Oregon. Mazama 1:204-230.

Moore, D. W. 1986. Systematic and Biogeographic Relationships among the Talpinae (Insectivora:Talpidae), Ph.D. dissertation, University of New Mexico, Albuquerque.

Мотокаша, M. 2004. Phylogenetic relationships with Talpidae (Mammalia: Insectivora). Journal of Zoology (London) 263:147- 157.

Mouchaty, S., A. Gullberg, A. Janke, and U. Arnason. 2000. The phylogenetic position of the Talpidae within Eutheria based on analysis of complete mitochondrial sequences. Molecular Biology and evolution 17:60-67.

Nylander, J. A. A. 2004. MrModeltest v2.2. Program distributed by the author. Evolutionary Biology Centre, Uppsala University. Uppsala, Sweden.

Palmer, F. G. 1937. Geographic variation in the mole Scapanus latimanus. Journal of Mammalogy 18:280-314.

RIDDLE, B. R. 1995. Molecular biogeography in the pocket mice (Perognathus and Chaetodipus) and grasshopper mice (Onychomys): the Late Cenozoic development of a North American arid lands rodent guild. Journal of Mammalogy 76:283-301.

Shinohara, A., K. L., Campbell, and H. Suzuki. 2003. Molecular phylogenetic relationships of moles, shrew moles, and desmans from the new and old worlds. Molecular Phylogenetics and Evolution 27: 247-258.

Sikes, R. S., and The Animal Care and Use Committee of the Amerlcan Society of Mammalogists. 2016. Guidelines of the American society of mammalogists for the use of wild mammals in research and education. Journal of Mammalogy 97:663-688.

Sмıтн, M. F. 1998. Phylogenetic relationships and geographic structure in pocket gophers in the genus Thomomys. Molecular Phylogenetics and Evolution 9:1-14.

Smith, M. F., and J. L. Patton. 1993. The diversification of South American murid rodents: evidence from mitochondrial DNA sequence data of the akodontine tribe. Biological Journal of the Linnean Society 50:149-177.

Swofford, D. L. 2002. PAUP: phylogenetic analysis using parsimony, version 4.0b10. Sinauer Associates. Sunderland, Massachusetts.

True, F. W. 1894. Diagnosis of new North American mammals. Proceeding U. S. Natural Museum 19:1-11.

Yates, T. L., And I. F. Greenbaum. 1982. Biochemical systematics North American moles (Insectivora:Talpidae). Journal of Mammalogy 63:368-374.

Yates, T. L., and J. Salazar-Bravo. 2005. Revision of the Scapanus latimanus, with the revalidation of a species of Mexican mole. Pp. 489-506, in Contribuciones mastozoológicas en Honor a Bernardo Villa (V. Sánchez-Cordero, and R. Medellín, eds.). Instituto de Biología, UNAM, Instituto de Ecología UNAM. Ciudad de México, México.

ZHAO, J., AND G. JIAN. 2015. Complete mitochondrial genoma of Condylura cristata (Unpublished). BGl Education Center, University of Chinese Academy of Sciences, Shenzhen, China.

Associated editor: Lisa and Robert Bradley

Submitted: March 27, 2021; Reviewed: April 27, 2021

Accepted: May 8, 2021; Published on line: May 28, 2021. 
